\title{
TOWARDS THE CREATION OF THE "NETWORK OF THE MOST INTERESTING VILLAGES". SELECTED PROBLEMS OF RURAL RENEWAL IN POLAND
}

\author{
Marcin WóJCIK \\ University of Łódź \\ Department of Regional and Social Geography \\ ul. Kopcińskiego 31, 90-142 Łódź \\ marcin.wojcik@geo.uni.lodz.pl
}

\begin{abstract}
Transformations that occur in Polish rural areas also impact tourism and recreation enterprises. Initiation of rural development programmes successfully activates processes of modernisation in many fields of social and economic life, including the material base (infrastructure), which is an essential element in the functioning of settlement systems. The aim of this study is to present selected results of the expert analysis of 50 Polish villages, which are characterised by a high concentration of cultural values - material, institutional and spiritual. The assessment of a group of rural settlements was meant to determine the potential for creating the Network of the Most Interesting Villages. The article presents the factual basis for such evaluation, the differentiation in groups of villages according to selected traits, especially those describing the infrastructural plane for developing the tourism and recreational functions.

The recipe for success includes many elements. The most important ones include attractive spatial configuration in which there is no shortage of central locations that are the focus of educational and recreational functions, the social awareness of the value of one's own heritage and the ability to describe it (the purpose of stay), the existence of long-lasting institutions referring to the historical memory and communal activities, the ability to create the media for narration placed in the internal environment, somewhat-formed path of its own development based on own resources (developed tourism functions), as well as participation in local and regional network of town with varying functions, and natural and anthropogenic environmental values (tourist regions).
\end{abstract}

Key words: rural renewal, social activity, places, Poland.

\section{Introduction}

In contemporary times, especially in the context of projects implemented with EU funds, village renewal is a very wide notion that includes revitalisation of various facilities, improvement of aesthetic qualities and development of public space, investment in infrastructure, consolidation of social capital and place identity, i.e. cuisine, cultural and educational activity, etc. (cf. Kłodziński et al. 2007; Wójcik 2010; Wilczyński 2012a; Idziak and Wilczyński 2013; Staszewska 2015). One of the weakest aspects of objective and realistic assessment of village cultural assets is absence of comprehensive information on their qualitative and quantitative scope. This information is fragmentary both in territorial 
and institutional terms. In the territorial dimension, areas established in terms of tourism intensity (guides, maps, online sources, discussion fora, etc.) and concentration of assets with considerable historical value (tourist regions and "strong" cultural regions of various kinds: historical, ethnographic) are better inventoried. In the institutional dimension, fragmentarism consists mainly in inconsistency of knowledge of the institutions responsible for keeping such data (e.g. heritage conservators, local government institutions, R\&D units), especially in terms of their spatial location and resulting various close-range (spatial, functional, social) links.

Attempts at taking stock and assessment of the size of preserved cultural heritage in rural areas, especially peripheral, requires knowledge derived from many sources, the more so as records are in many cases obsolete, mainly due to contemporary processes of destroying facilities with high cultural value, in particular privately-owned (historic farmstead buildings). Institutionalised actions are an opportunity to reverse unfavourable trends in this respect, i.e. in addition to local activity of leaders interested in creative development of cultural heritage they assume the form of a network: a group linked by an overarching goal, with a common organisational base, rules and development plans with central regulatory bodies in this area.

\section{Research objective and methodology}

The purpose of the paper is to interpret the result of an expert assessment of 50 Polish villages characterised by high concentration of cultural assets: material, institutional, and spiritual. The assessment of a group of villages served to see whether it is possible to set up a network of the Most Interesting Villages. This paper presents the scope (substantive basis) of assessment, diversity of the group of villages in terms of selected characteristics, and basic problems of preservation and shaping of valuable ruralistic systems. ${ }^{1}$

The experience of the Opolskie Voivodeship village renewal programme, implemented for over 15 years, was the basis for a substantive concept and organisational basis of a national network of villages whose assets may be of interest to tourists from Poland and abroad (cf. Idziak and Wilczyński 2013). ${ }^{2}$ The original idea for a network of interesting villages was created in France and found many followers, mainly in the European Union, Canada and Japan (cf. Wilczyński 2012b). The basic development goal is, in any case,

1 The project "Creation of a Network of the Most Interesting Villages" was commissioned by the Foundation of Assistance Programmes for Agriculture (FAPA) subordinate to the Ministry of Agriculture and Rural Development between 16 January and 31 May 2015. Its initiator and main expert was Ryszard Wilczyński (currently a Sejm deputy). Project substantive manager and research organiser: Professor of the University of Lodz Marcin Wójcik. Interdisciplinary research team composed of: Professor of the Adam Mickiewicz University Sylwia Staszewska (Adam Mickiewicz University, Poznań), Piotr Staszewski, MSc Eng (practitioner, architect, Poznań), Konrad Czapiewski, PhD and Edyta Regulska, PhD (Polish Academy of Sciences, Warsaw), Paulina Tobiasz-Lis, PhD, Karolina Dmochowska-Dudek, PhD, Tomasz Napierała, PhD, Pamela Jeziorska-Biel, PhD, Małgorzata MarksKrzyszkowska, PhD, Marcin Feltynowski, PhD (University of Lodz, Lodz), Magdalena Dej, PhD, Łukasz Sykała, MSc (Institute of Urban Development, Krakow), Krzysztof Janc, PhD, Paulina Dudzik-Deko, PhD Eng (University of Wroclaw, Wroclaw). The operator of the Network of the Most Interesting Villages being established in the Polish Network for Village Renewal and Development (PSORW) with its Secretariat in the Gogolin Town Hall (Opolskie Voivodeship).

2 Anyone interested in the history of the village renewal programme in Opolskie Voivodeship should refer to the papers by W. Idziak and R. Wilczyński (2013) and visit http://www.dziedzictwowsiopolskiej.pl/and http:// www.odnowawsi.eu/that feature numerous materials on the substantive and organisational basis of projects from the past 15 years. 
prevention of unfavourable demographic and economic processes such as depopulation, decline in economic activity, property value decrease, loss of cultural assets, etc. The Polish project is specific because it shifts emphasis from "the most beautiful" to "the most interesting", which is connected on the one hand with quite extensive degradation of the value of material heritage throughout Poland, and on the other hand with stressing the role of various socio-economic processes that in modern times lead to greater significance of villages and their supra-local influence. Creation of such a network is a chance to cultivate rusticity and preserve rural cultural heritage, it offers villages opportunities for development and improvement of the quality of life of the population (NiedźwiedzkaFilipiak; Wilczyński 2015).

Creation of a Network of the Most Interesting Villages is a long-term process accompanied by many objectives in various aspects of rural settlement functioning. The operator of the emerging brand product is the Polish Network for Village Renewal and Development (PSORW), an association of about 50 entities, mainly local authorities, whose purpose is to exchange experience and knowledge of good practices in socio-economic growth of rural areas. ${ }^{3}$ The activity of this association was key to institutionalisation of creation of a Network of the Most Interesting Villages, and thus to launching the mechanism for selection of candidates, developing rules and development of an elite group of rural settlements. The idea that emerged during initial experience of Poland as an EU Member State should be put into practice in 2017 when the network will be launched on the basis of uniform rules of an action plan, creation of image and a tourist brand, etc.

In 2015 activity of the Polish Network for Village Renewal and Development was focused on implementation of the Network project in terms of assessment of cultural values of initial 50 villages from a list of 100 units selected by association members on the basis of their own information and information provided by heritage conservators and local government institutions from the regional level (Fig. 1). The project was implemented using the funds from the Rural Development Programme (2007-2013) as commissioned by the Foundation of Assistance Programmes for Agriculture (FAPA) subordinate to the Ministry of Agriculture and Rural Development between January and May 2015. ${ }^{4}$ The 50 villages from the list of 100 villages were selected by the project substantive director on the basis of an initial assessment of all settlement units on the basis of three traits: preservation of historical spatial layout and degree of its transformation, social activity, and matching natural and anthropogenic assets of the region. One of the rules was that a village from every Polish voivodeship would be invited to participate in the project (at least 1 village recruited from each voivodeship). A pilot project was implemented earlier in Opolskie Voivodeship on the basis of funds from the National Rural Network (KSOW).

The location of the villages from the list provided by the Foundation of Assistance Programmes for Agriculture is primarily a function of the state of preservation of cultural, especially material, heritage of Polish rural areas. The spatial distribution of the 50 villages selected for the project largely followed the distribution of all the villages on the list. The number of villages was also influenced by involvement of regional local government institutions and cultural heritage protection bodies in the project. The project was very popular in Lubuskie, Opolskie, Dolnośląskie and Warmińsko-Mazurskie Voivodeships.

\footnotetext{
3 More information at: http://www.psorw.odnowawsi.pl/.

${ }^{4}$ FAPA - Foundation of Assistance Programmes for Agriculture.
} 


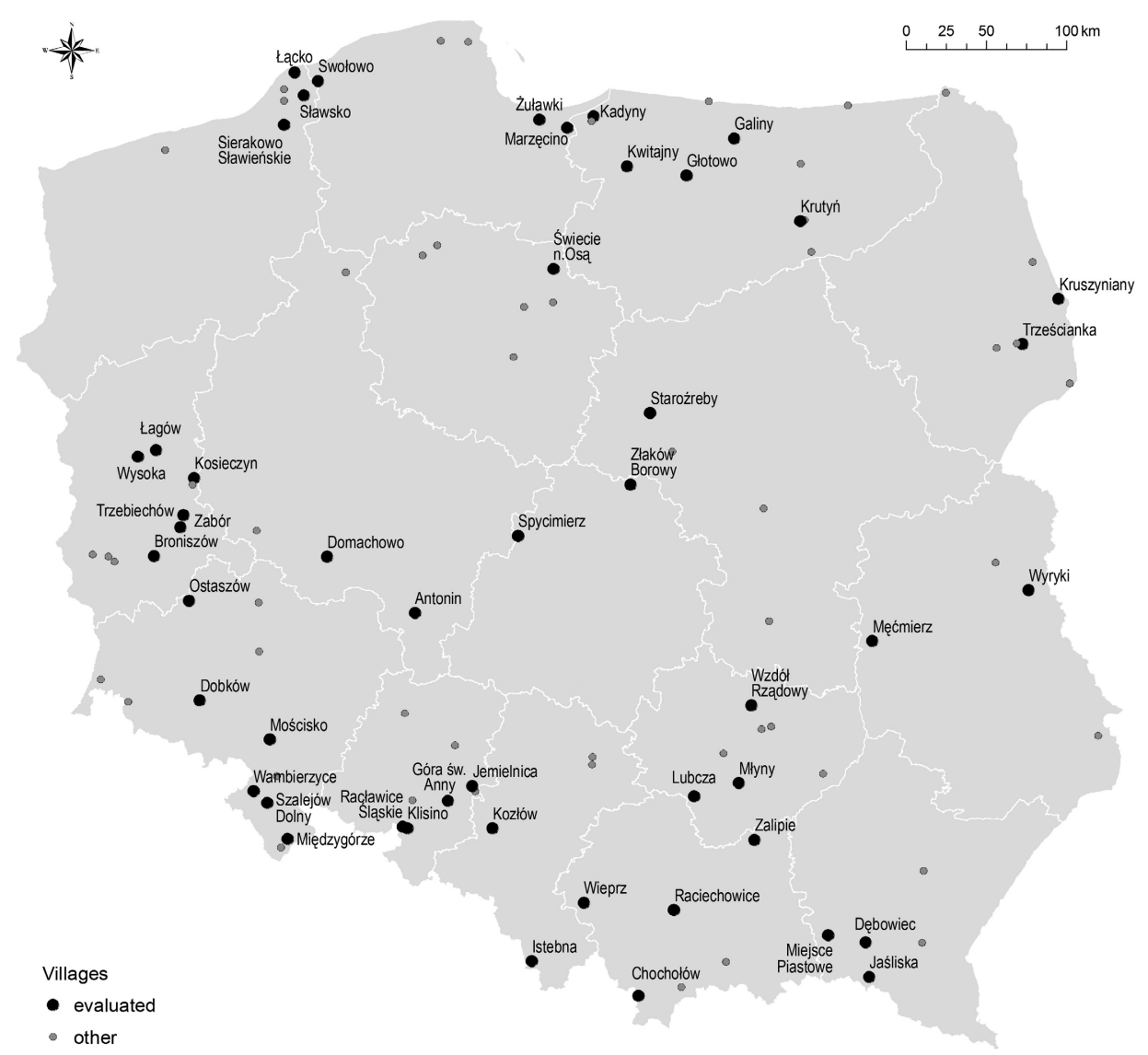

Fig. 1. Locations of the villages submitted for assessment (100) and assessed (50) between January and May 2015. Source: own study.

The location of the villages in Poland shows that the greatest resources of material cultural heritage can be found in regions dominated by more permanent residential and farm buildings (brick, rock, wattle and daub) before World War II, i.e. in areas annexed by Poland in 1945 (Zachodniopomorskie, Lubuskie, Dolnośląskie, Opolskie and Warmińsko-Mazurskie Voivodeships). The state of preservation of original spatial and physiognomic layout depended to a great extent on intensity of post-war rural settlement transformation under the influence of industrialisation and urbanisation. There are relatively many villages interesting from that point of view on agricultural areas of Podlaskie, Lubelskie, Małopolskie and Podkarpackie Voivodeships. Destruction was irreversible in the central regions, i.e. in Łódzkie, Mazowieckie, Świętokrzyskie, and Kujawsko-Pomorskie Voivodeships, where wooden buildings were replaced by brick ones and the process was characterised by absence of deliberation on the historical value of ruralistic systems. As a consequence, in central Poland material cultural heritage of villages can be seen almost exclusively in open air museums.

Village potential assessment is based on a multi-criteria method of field and desk studies using an evaluation sheet or a Village Assessment Card. The card is the result of 
attempts of many years to develop a tool for assessment of cultural resources of villages in many aspects (cf. Niedźwiedzka-Filipiak and Wilczyński 2015). In the card, point weights are attributed to substantive issues and their components, the points are divided between aspects and finally they are assigned a specific number of points during an expert assessment (cf. Niedźwiedzka-Filipiak and Wilczyński 2015, pp. 98-100).

The idea of identification of cultural resources of interesting villages refers to a division of villages into two types: villages of cultural heritage with relatively significant historical, especially architectural and physiognomic, assets and villages of experience and emotions that can be attractive due to their specificity and attractions. In this concept, the connection between creating a brand product and implementation of the paradigm of revitalisation, including internal village development, is important (cf. Niedźwiedzka-Filipiak and Wilczyński 2015).

Village assessment is based on criteria covering three main issues: resources, specificity, and climate (cf. Niedźwiedzka-Filipiak and Wilczyński 2015; Tab. 1). Their joint analysis decides on the overall opinion on the quality of a place and its offer, which translates into satisfaction of the recipients who, during their stay, are accompanied by emotional states. The concept of network creation assumes that cognitive values are the reason for stay. Stay must nonetheless be defined in a precise way, i.e. verbalised in the form of a "narrative" referring to a specific area, i.e. "area made available", and a route along which we get to know subsequent parts, i.e. a route making available village assets (cf. Niedźwiedzka-Filipiak and Wilczyński 2015, p. 12). The nature of a place narrative is routinised to a specific route and time necessary to get to know and trigger effects in the form of experiences and emotions.

\section{Research results}

A positive mark, and hence conclusion on having sufficient determinants for a village to participate in the created network, is to obtain at least 35 points out of 100 and absence of characteristics that disqualify a village altogether. 46 out of 50 villages invited to the project were evaluated positively. The four villages that were assessed negatively included: Klisino (Opolskie Voivodeship, 30 points), Wzdół Rządowy (Świętokrzyskie Voivodeship, 27.5 points), Złaków Borowy (Łódzkie Voivodeship, 26 points) and Lubcza (Świętokrzyskie Voivodeship, 20 points).

The results of the assessment varied greatly. The difference between the village with the highest score, i.e. Istebna (Śląskie Voivodeship, 79 points), and the one with the lowest score, i.e. Lubcza, amounted to 59 points. The average score of all fifty villages is 51.7 points, and the standard deviation -14.3 points (cf. Fig. 2). The division of the analysed population according to the average, average + standard deviation and average - standard deviation, i.e. into four groups, was compliant with the project assumptions. The boundary value between the two best groups (average + standard deviation), i.e. 66 points, corresponds to the level assumed at the project onset, above which villages may receive certification, that is become the network members soon.

The boundary value between two groups of villages with lower scores (average - standard deviation), i.e. 37.4 points, is almost identical to the level below which a village was assessed negatively (35 points). 
Table 1. Village assessment issues and aspects

\begin{tabular}{|c|c|c|c|}
\hline \multicolumn{2}{|r|}{ Issues } & Aspects & $\begin{array}{c}\text { Total } \\
\text { number } \\
\text { of points } \\
\text { per issue }\end{array}$ \\
\hline \multirow{3}{*}{ 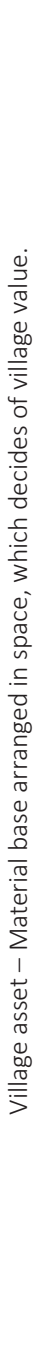 } & $\begin{array}{l}\text { 1. Spatial arrangement } \\
\text { and the image of the } \\
\text { village } \\
\text { - Historic value of } \\
\text { facilities, technical con- } \\
\text { dition and visual aspect } \\
\text { of facilities, quality } \\
\text { and functionality of } \\
\text { interesting areas with } \\
\text { communication and } \\
\text { service areas and areas } \\
\text { that create a landsca- } \\
\text { pe framework on the } \\
\text { outside. }\end{array}$ & $\begin{array}{l}\text { 1. Spatial order - village silhouette } \\
\text { 2. Spatial order - general image } \\
\text { 3. Spatial order - centre/central spot } \\
\text { 4. Spatial order - entry zones } \\
\text { 5. Spatial order - entrance roads } \\
\text { 6. Monuments, facilities, forms in space of particular historical } \\
\text { value - historical ruralistic system } \\
\text { 7. Monuments, facilities, forms in space of particular historical } \\
\text { value - historical facilities } \\
\text { 8. Monuments, facilities, forms in space of particular historical } \\
\text { value - village characteristic } \\
\text { 9. Monuments, facilities, forms in space of particular historical } \\
\text { value- farmstead buildings and other buildings of significant } \\
\text { historical and architectural value } \\
\text { 10. Buildings and land (architecture, technical condition, extent } \\
\text { and nature of transformations) - buildings } \\
\text { 11. Buildings and land (architecture, technical condition, extent } \\
\text { and nature of transformations) - building surroundings (yards, } \\
\text { gardens, orchards) } \\
\text { 12. Buildings and land (architecture, technical condition, extent } \\
\text { and nature of transformations) - fences (condition, adequacy) } \\
\text { 13. Public space and its elements } \\
\text { 14. Natural and landscape elements, areas and types of greenery } \\
\text { inside a village } \\
\text { 15. Quality of surroundings and links with the surroundings } \\
\text { - village landscape framework visible from the inside } \\
\text { 16. Quality of surroundings and links with the surroundings } \\
\text { - vantage points with a view of the surroundings } \\
\text { 17. Quality of surroundings and links with the surroundings } \\
\text { - valuable natural and landscape elements in direct vicinity } \\
\text { of the village }\end{array}$ & 30 \\
\hline & $\begin{array}{l}\text { 2. Tourist infrastructure } \\
\text { - Facilities that enable } \\
\text { taking advantage of } \\
\text { village assets. }\end{array}$ & $\begin{array}{l}\text { 18. Accommodation facilities } \\
\text { 19. Restaurants } \\
\text { 20. Places dedicated to tourists (car park, stopping place, rest) } \\
\text { 21. Facilities offering active leisure } \\
\text { 22. Connectivity and the Internet }\end{array}$ & 20 \\
\hline & $\begin{array}{l}\text { 3. Making assets avail- } \\
\text { able - infrastructure } \\
\text { that serves getting } \\
\text { to know village assets } \\
\text { and method of making } \\
\text { available (route and } \\
\text { description forms) }\end{array}$ & $\begin{array}{l}\text { 23. Marking out a route making village assets available } \\
\text { - definition of attractiveness/cognitive assets of the village } \\
\text { 24. Marking out a route making village assets available } \\
\text { - presentation of the assets of the village } \\
\text { 25. Route beginning place (s) } \\
\text { 26. Rest areas (asylums) for tourists } \\
\text { 27. Moving along the route } \\
\text { 28. Route description system } \\
\text { 29. Existing routes and trails }\end{array}$ & 20 \\
\hline \multicolumn{2}{|c|}{$\begin{array}{l}\text { Village specificity } \\
\text { - A set of elements that } \\
\text { make a village unique, } \\
\text { decide of its recognisabil- } \\
\text { ity. Specificity creates } \\
\text { uniqueness of a place, its } \\
\text { identity and consequently its } \\
\text { recognisability. }\end{array}$} & $\begin{array}{l}\text { 30. Definition of the reason behind stay } \\
\text { 31. Communication and development of specificity/attractive- } \\
\text { ness - information materials, website, etc. } \\
\text { 32. Communication and development of specificity/attractive- } \\
\text { ness - characteristics of the place, visual information system, etc. } \\
\text { 33. Communication and development of specificity/attractive- } \\
\text { ness - services, products, souvenirs } \\
\text { 34. Getting to know village specificity and learning } \\
\text { - cyclical of ad hoc events } \\
\text { 35. Getting to know village specificity and learning } \\
\text { - artistic activities, workshops, field games }\end{array}$ & 15 \\
\hline
\end{tabular}


Impressions (climate) - A set of determinants that create impressions, shape imagination and stimulate the senses. The climate of a place exists in the symbolic sphere described by spiritual legacy and emotions emerging under the influence of external stimuli.
36. Promotion of rural values

37. The life of a village and its residents, safeguarding traditions and customs

38. Space of the senses

39. Supra-local impact of attractiveness

Source: Own study on the basis of: I. Niedźwiedzka-Filipiak and R. Wilczyński (2015).

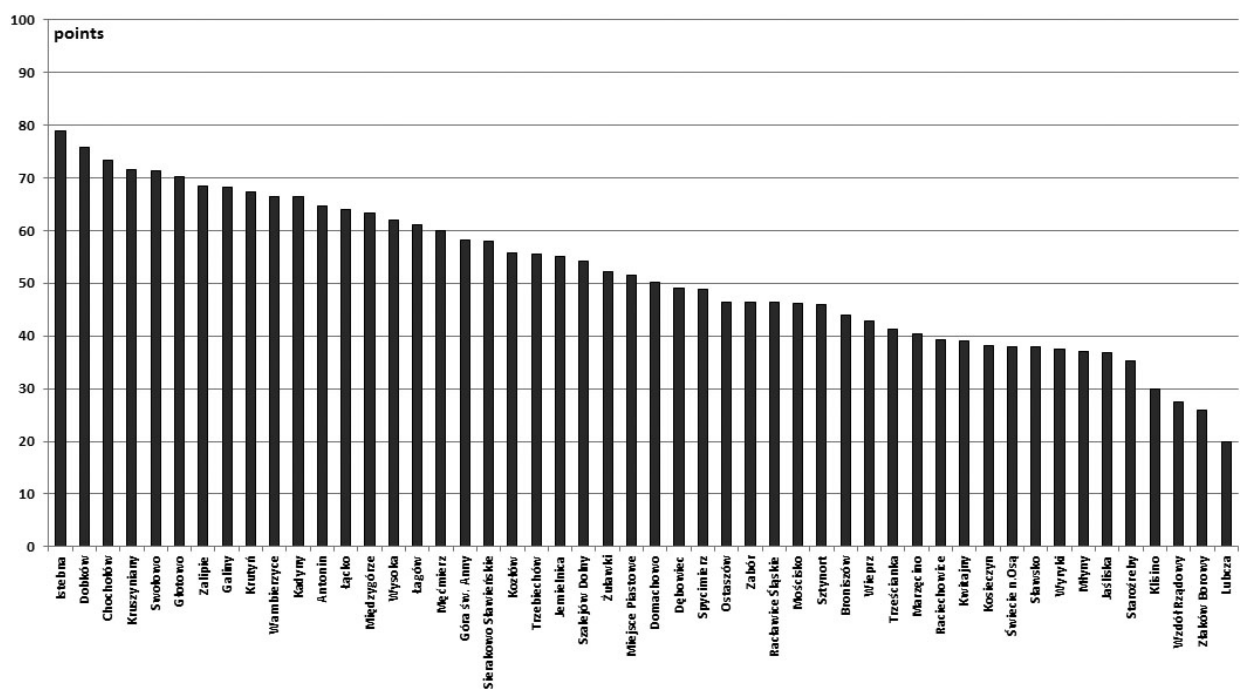

Fig. 2. General results of the expert analysis of 50 selected villages Source: own study.

A relatively even score distribution of the expert analysis of 50 villages allowed to extend the classification into five groups, with the spread of the three middle groups amounting to 10 points (Table 2). Thus the population was divided into villages with a very high (65 points and more) and high potential for participation in the network (55 64.99 points), average potential (45-54.99 points) and low (35-44.99) and very low potential (below 35 points).

Spatial distribution of villages from individual groups allows to identify certain regularities (Fig. 3). It reveals that there is a connection between the location of the village (region) and its score. Villages in the regions where cultural heritage is best preserved, i.e. in Dolnośląskie, Lubuskie, Opolskie, Zachodniopomorskie and Warmińsko-Mazurskie Voivodeships, received relatively higher scores. Villages with very high and high potential for participation in the Network of the Most Interesting Villages create spatial groupings - prospective clusters, which may facilitate their further functioning on the tourist services market (exchange of experience, common problems, possibility to finance development from the same sources). In other regions, candidates with the highest scores are isolated cases distinguished mainly by high awareness of their assets and the already existing own tourist brand, i.e. Kruszyniany, Chochołów, Zalipie, Istebna, Męćmierz. 
Table 2. Villages participating in the project by score group

\begin{tabular}{|c|c|c|}
\hline Group & $\begin{array}{l}\text { Number } \\
\text { of villages }\end{array}$ & Villages \\
\hline Up to 35 points & 4 & Klisino, Wzdół Rządowy, Złaków Borowy, Lubcza \\
\hline 35-44.99 points & 13 & $\begin{array}{l}\text { Broniszów, Wieprz, Trześcianka, Marzęcino, Raciechowice, Kwitajny, } \\
\text { Kosieczyn, Świecie on Osa, Sławsko, Wyryki, Młyny, Jaśliska, Staroźreby }\end{array}$ \\
\hline $45-54.99$ points & 11 & $\begin{array}{l}\text { Szalejów Dolny, Żuławki, Miejsce Piastowe, Domachowo, Dębowiec, } \\
\text { Spycimierz, Ostaszów, Zabór, Racławice Śląskie, Mościsko, Sztynort }\end{array}$ \\
\hline 55-64.99 points & 11 & $\begin{array}{l}\text { Antonin, Łącko, Międzygórze, Wysoka, Łagów, Męćmierz, Góra św. Anny, } \\
\text { Sierakowo Sławieńskie, Kozłów, Trzebiechów, Jemielnica }\end{array}$ \\
\hline 65 points and more & 11 & $\begin{array}{l}\text { Istebna, Dobków, Chochołów, Kruszyniany, Swołowo, Głotowo, Zalipie, } \\
\text { Galiny, Krutyń, Wambierzyce, Kadyny }\end{array}$ \\
\hline
\end{tabular}

Source: own study.

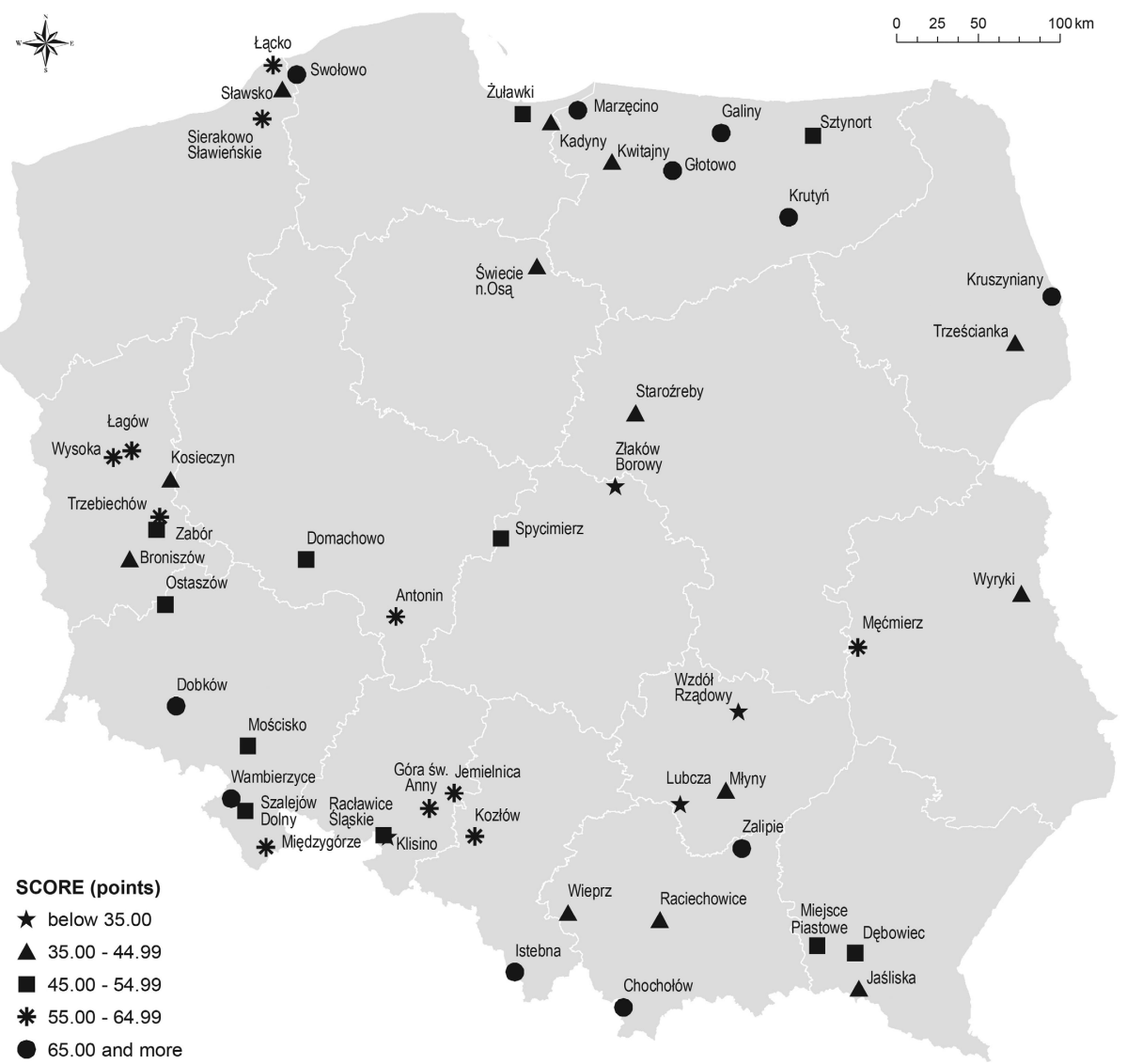

Fig. 3. Scores of villages (by group)

Source: own study. 
Among five main aspects of assessment of the villages, the highest number of points was awarded for spatial arrangement and image of the villages (Fig. 4). The subsequent places belonged to the method in which the inhabitants propose to share the village resources and the specificity of the village, i.e. the set of elements determining the recognisability of the village and its offer. The aspects with the lowest score are related to existence and functioning of tourist infrastructure, that is all facilities aimed at keeping the visitors in the village for as long as possible, and thus building or reinforcing the economic strength of villages. Therefore, the existing resources and their social awareness in a large part of villages create a significant cognitive value. However, the deficits resulting from poor promotion of valuable aspects and the lack of the possibility to stay in the locality longer are the main barriers for joining the network for the majority of villages.

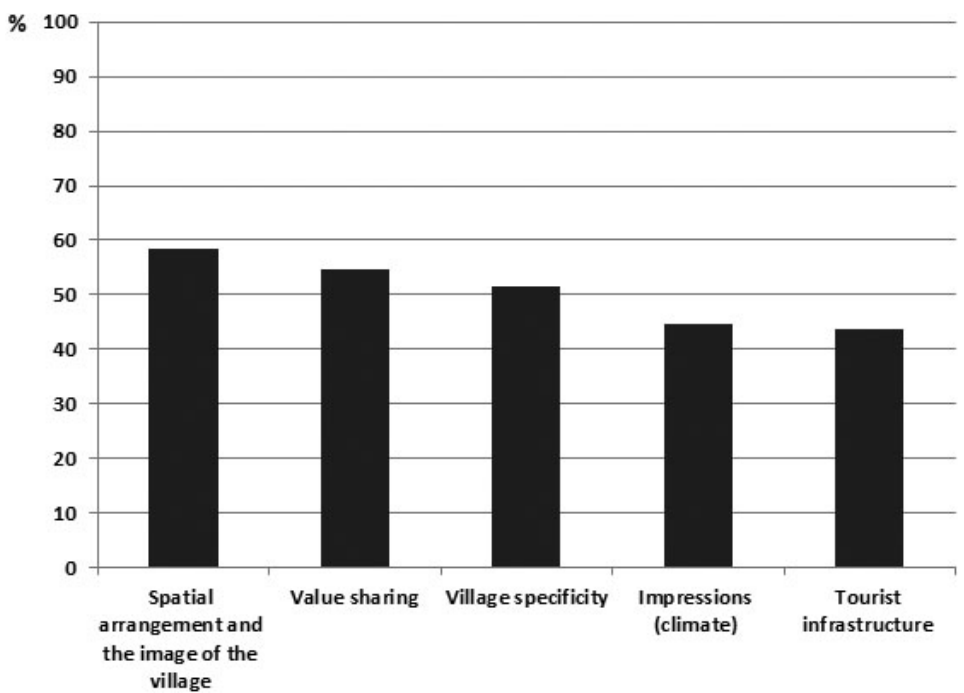

Fig. 4. Average value of individual aspects of assessment as the proportion of the maximum possible score (\%) Source: own study.

Table 3. Villages - leaders of the substantive analysis

\begin{tabular}{|c|c|c|c|c|}
\hline $\begin{array}{l}\text { Spatial arrange- } \\
\text { ment and the im- } \\
\text { age of the village }\end{array}$ & $\begin{array}{c}\text { Tourist } \\
\text { infrastructure }\end{array}$ & $\begin{array}{l}\text { Value sharing } \\
\text { (route) }\end{array}$ & Village specificity & $\begin{array}{c}\text { Impressions } \\
\text { (climate) }\end{array}$ \\
\hline $\begin{array}{l}\text { - Głotowo (Warmiń- } \\
\text { sko-Mazurskie) } \\
\text { - Galiny (Warmiń- } \\
\text { sko-Mazurskie) } \\
\text { - Kadyny (Warmiń- } \\
\text { sko-Mazurskie) } \\
\text { - Chochołów } \\
\text { (Małopolskie) } \\
\text { - Męćmierz } \\
\text { (Lubelskie) }\end{array}$ & $\begin{array}{l}\text { - Międzygórze } \\
\text { (Dolnoślqskie) } \\
\text { - Antonin } \\
\text { (Wielkopolskie) } \\
\text { - Krutyń (Warmiń- } \\
\text { sko-Mazurskie) } \\
\text { - Istebna (Śląskie) } \\
\text { - Kozłów (Śląskie) } \\
\text { - Kruszyniany } \\
\text { (Podlaskie) } \\
\text { - Wambierzyce } \\
\text { (Dolnośląskie) }\end{array}$ & $\begin{array}{l}\text { - Krutyń (Warmiń- } \\
\text { sko-Mazurskie) } \\
\text { - Łącko (Zachodnio- } \\
\text { pomorskie) } \\
\text { - Głotowo (Warmiń- } \\
\text { sko-Mazurskie) } \\
\text { - Istebna (Śląskie) } \\
\text { - Swołowo } \\
\text { (Pomorskie) } \\
\text { - Dobków } \\
\text { (Dolnośląskie) }\end{array}$ & $\begin{array}{l}\text { - Zalipie } \\
\text { - } \text { Dabopolskie) } \\
\text { (Dolnośląskie) } \\
\text { - Kruszyniany } \\
\text { (Podlaskie) } \\
\text { - Swołowo } \\
\text { (Pomorskie) } \\
\text { - Domachowo } \\
\text { (Wielkopolskie) }\end{array}$ & $\begin{array}{l}\text { - Dobków } \\
\text { (Dolnośląskie) } \\
\text { - Zalipie } \\
\text { (Małopolskie) } \\
\text { - Chochołów } \\
\text { (Małopolskie) } \\
\text { - Swołowo } \\
\text { (Pomorskie) } \\
\text { - Istebna (Śląskie) }\end{array}$ \\
\hline
\end{tabular}

Source: own study. 
More precise specification of aspects that received the highest and the lowest score during the analysis allows to identify strengths and weaknesses of the villages from the perspective of participation in the Network of the Most Interesting Villages, on the one hand, and to identify the key areas of intervention to increase the attractiveness of the villages, on the other hand. Aspects with the highest score include:

1) Nature and landscape in the village - natural diversity and landscape in the village received relatively the highest marks, primarily due to relatively well-preserved and kept vegetation in public space and its link to the nature surrounding the village. Thanks to their location in the Polish regions with attractive natural assets (diversified lie of the land, forests), numerous villages have a varied physiography, including such elements contributing to good perception of landscape as rivers, lakes, inliers, outcrops, positions of valuable flora.

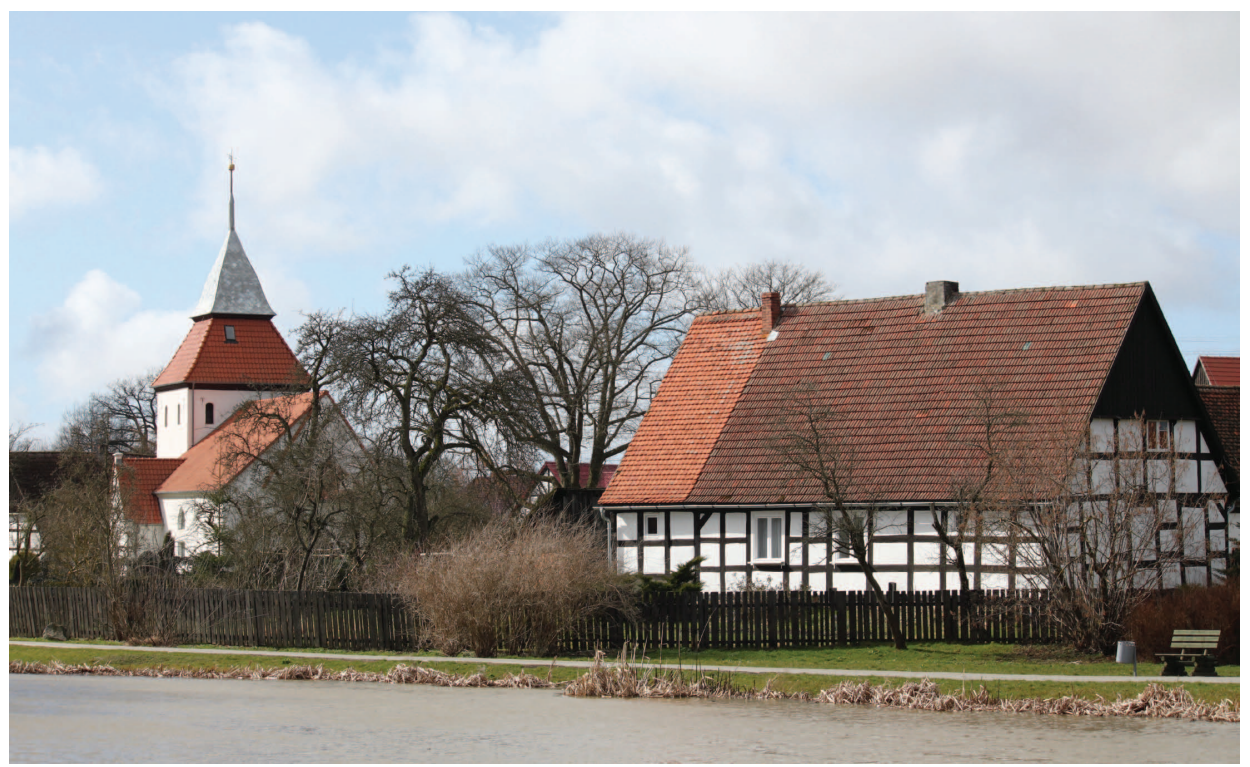

Photo 1. Swołowo - an example of a candidate to the network with significant assets based on preserved material cultural heritage. Photo: M. Wójcik.

2) Distinctive elements of the village - every village has its original characteristics resulting from natural and cultural (regional and local) factors. The majority of villages can distinguish and highlight those elements of their specificity that are explicitly associated with those localities and differentiate them from other participants of the network of the most interesting villages and the village settlement network in Poland.

3) Traffic routes - the majority of villages have dense settlement systems and are clearly separated from other villages, therefore, well-formed traffic routes add important variety and are often characterised by regularity of old trees along the roads, fields and lie of the land.

4) Historic structures - the process of selection of villages for assessment of their potential assumed that material cultural heritage played an important role in creating 
the brand of the majority of villages. The villages were characterised by a variety of architectural and landscape forms, including sacred, residential, farm, public utility buildings, as well as the so-called small architecture.

5) Surrounding nature and landscape - the majority of villages are located in regional peripheries, and thus landscape is transformed to a relatively small extent (suburbanisation, industrialisation, transport investments, etc. that influence the landscape). The majority of villages are located in attractive regions for tourism, i.e. the coast, lake district and mountains.

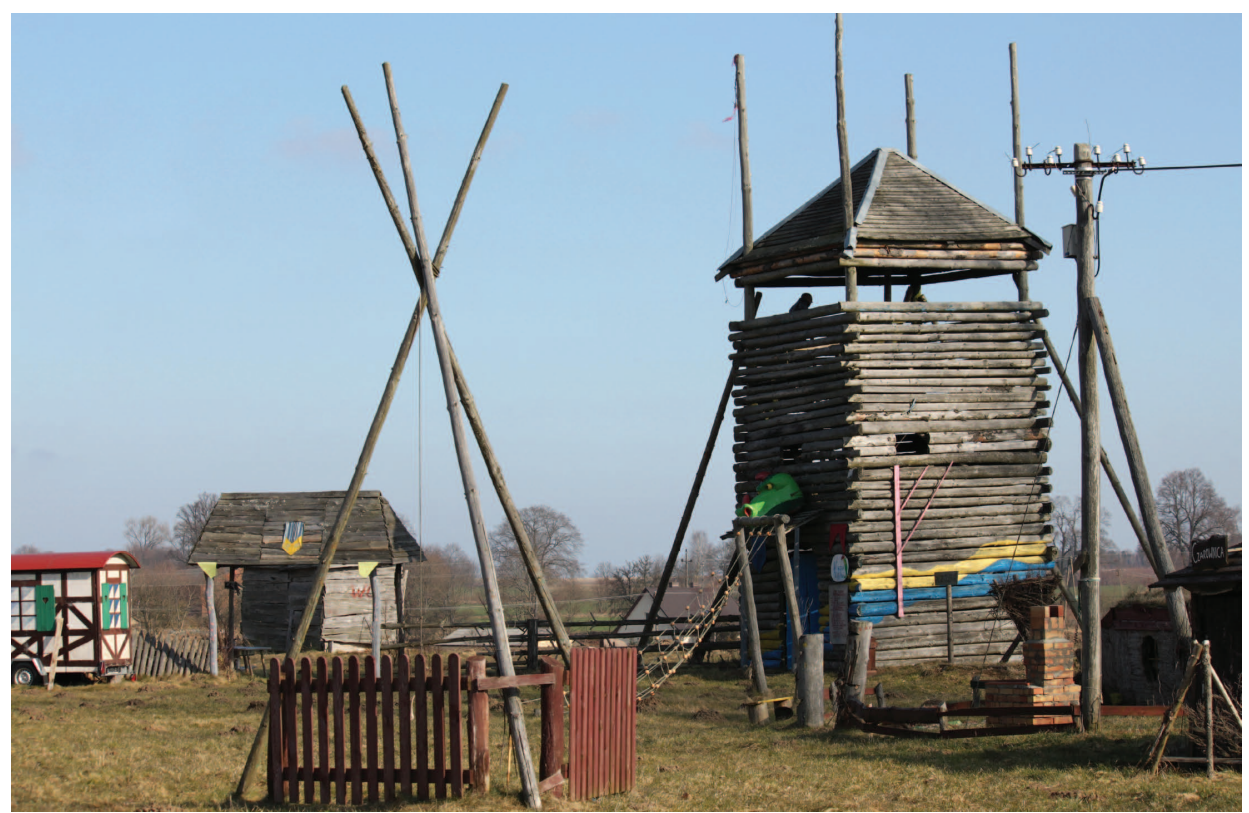

Photo 2. Sierakowo Sławieńskie - an example of a candidate to the network with significant non-material assets (village of "impressions and emotions"). Photo: M. Wójcik.

6) Ruralistic system - the villages represent various morphogenetic systems, most often compact, but numerous villages represent old settlement forms, such as villages built along several roads, oval-shaped villages, linear villages and row villages. Those forms are most often characterised by good or very good preservation of the original settlement system.

7) Landscape framework (panoramas and scenic axes) - diversified lie of the land and internal part of the village devoid of new structures usually provide an opportunity to watch the area surrounding the village (from beauty spots or through "windows" in the settlement landscape), as well as along the axis cutting through the village.

The following aspects received the worst scores:

1) Type and condition of fencing - one of the most dissonant elements in rural landscape. Inadequacy of this element with respect to precious natural and cultural objects, extreme differences in terms of materials and aesthetics, as well as internal 
inconsistency contribute to the greatest extent to reducing the attractiveness of the villages.

2) Technical condition of buildings - in the majority of villages the technical condition of buildings may lead to the loss of crucial cultural resources in the coming years. Other threats include provisional repairs, destruction of architectural details and the lack of social understanding of the value of objects, in particular farm facilities.

3) Services, products, souvenirs - the majority of villages do not promote themselves by selling even small souvenirs or products related to their specificity.

4) Route description function - the villages very seldom have full description of the route around the accessible area and of precious objects or important events.

5) Places for tourists - the lack of places dedicated to tourists is one of the greatest obstacles to keeping the visitors longer in place and to encourage them to learn more about a given place and reflect on it.

6) Visual information system - the information which would create narration of the place and specific symbols for the purpose of describing the original places and walking routes is most often missing.

7) Surroundings of the buildings - surroundings of the buildings are usually inconsistent with their nature; the most negative examples of such phenomenon include provisional extensions, mess on the property and replacement of traditional broadleaf vegetation with coniferous one.

The assessment and analysis of the collected material allows to conclude that there is a very high variation in regional cultural heritage resources with respect to architectural and physiognomy types and their preservation. In this respect, the highest potential for participation in the network is recorded mainly in villages located in the areas incorporated by Poland in 1945 (Warmińsko-Mazurskie, Lubuskie, Dolnośląskie, Opolskie, Zachodniopomorskie voivodeships). The degree to which rural material heritage is preserved results largely from differences in building materials used and the standard of the buildings. The most negative developments concerned the preservation of cultural heritage in central Poland (Łódzkie, Mazowieckie, Kujawsko-Pomorskie, Świętokrzyskie voivodeship), where post-war transformations led to total annihilation of wood buildings which nowadays are encountered almost exclusively in open-air ethnographic museums. Complexes of buildings made of more durable materials (stone, brick, wattle and daub) and characterised by a higher living standards, taken over from resettled German communities, are now the basis for identification of villages suitable for the network, with a very high potential in this regard, although in many cases the degradation of objects is already very advanced.

\section{Discussion}

Regional peripheries, where the majority of villages with a high potential for participation in the network are located, should be seen as an area of innovative actions which may increase their social and economic rank. Rural peripheral areas comprise numerous assets which, if appropriate instruments are applied, may be transformed into attractive places 
of leisure, living and, thanks to new technologies, also work. Villages with adequately high potential for participation in the network may in future become local drivers of socio-economic development.

The most urgent development problem of the analysed villages is to preserve their assets, in particular valuable historic ruralistic systems (layout and structures) in the condition enabling their appropriate presentation and aesthetic reception. Degradation of valuable buildings, in particular privately owned (e.g. homesteads) is extensive and very few villages may offer comprehensively preserved buildings. The renewal processes, and often even basic protection of buildings against degradation, are negatively affected by low social awareness of historic value and the lack of responsibility for transferring the heritage to subsequent generations. For numerous villages with valuable architectural assets and ruralistic systems, the coming 15-20 years will be decisive, since it is the period where the basic assets, which now attract the development and rural renewal institutions and enthusiasts of historic heritage to the village, may be destroyed.

One of the features which reduces the potential of almost all analysed villages is the poor aesthetics of fencing, in particular those of private properties. At the current stage of rural landscape transformations, fencing is the least original element of villages. The majority of fences are cheap substitutes of what should be an element completing the coherent architectural and physiognomic environment.

Social activity of residents is an important determinant of contemporary transformations of villages with a high potential for joining the network. This activity may be interpreted as the symptom of "new" rusticity related to the fact that numerous rural areas are entering the post-production stage of development. The main characteristic of "new" rusticity is the fact that villages are treated as an alternative to urban (urbanised) living and working environment, which demonstrates the increased awareness of rural assets. This concerns both new residents fascinated by original rural heritage and opportunities brought by its creative development and some locals who are increasingly interested in their identify and possibilities of obtaining profits from services for tourists and social groups searching for new cultural experiences and sensitive to impressions offered by rural environment.

The key to success is a combination of numerous elements that should be noticed and appreciated. The most important ones include attractive spatial layout with central points where sightseeing and leisure functions, social awareness of heritage assets and ability to talk about them (specification of the reason for staying), existence of long-lasting institutions referring to historical memory and community action, ability to create narration carriers in internal environment, established path of own development based on own resources (developed tourist functions), as well as functioning within a local and regional network of villages with various functions and natural and anthropogenic assets (tourist regions).

Support from local governments is an extremely important development factor of interesting villages and their participation in the network, since it is the local governments that decide about the launch of various promotional, institutional and legal instruments. Political and administrative wavering and the lack of long-term vision for development of villages, including high expectations in the short time, may lead to weakening of participation in the network (e.g. the loss of key resources, decline in activity of the local community, internal competitiveness). Each village with identified high potential for par- 
ticipation in the network, apart from characteristics shared by all members (typical set of characteristics decisive for success), has some unique development determinants, including original resources and only the local social environment, i.e. decision-makers, leaders and communities, are able to notice, understand and appropriately promote such assets.

\section{References}

Idziak W., Wilczyński R., 2013, Odnowa wsi. Przestrzeń, ludzie, działania, FAPA, Warszawa.

Kłodziński M., Błąd M., Wilczyński R. (eds.), 2007, Odnowa wsi w integrujq̨cej się Europie, IRWiR, Warszawa.

Niedźwiedzka-Filipiak I., Wilczyński R., 2015, Walory miejscowości - tworzywem Sieci Najciekawszych Wsi, Marshal's Office of Opolskie Voivodeship, Opole.

Staszewska S., 2015, Rola wiedzy środowiskowej mieszkańców w procesie odnowy wsi, Studia Obszarów Wiejskich, 40, pp. 159-167.

Wilczyński R., 2012a, Odnowa wsi z wykorzystaniem środków europejskich - niewykorzystana szansa na rewitalizację, Architektura Krajobrazu, Studia i Prezentacje, 2 (35), pp. 4-22.

Wilczyński R. (ed.), 2012b, Sieć Najpiękniejszych Wsi. Opracowanie eksperckie projektu, PROW, KSOW, Opole.

Wójcik M., 2010, Struktura i działanie - geograficzno-społeczna interpretacja oddziaływania funduszy Unii Europejskiej na przykładzie programu „Odnowa wsi”, Studia Obszarów Wiejskich, 24, pp. 186-201. 